\title{
Evidence That Androgen Acts Through NMDA Receptors to Affect Motoneurons in the Rat Spinal Nucleus of the Bulbocavernosus
}

\author{
Cynthia L. Jordan, ${ }^{1}$ Scott E. Christensen, ${ }^{2}$ Robert J. Handa, ${ }^{3}$ Jennifer L. Anderson, ${ }^{3}$ Wendy A. Pouliot, ${ }^{3}$ and \\ S. Marc Breedlove 1 \\ ${ }^{1}$ Neuroscience Program and Psychology Department, Michigan State University, East Lansing, Michigan 48824, \\ ${ }^{2}$ Department of Psychology, University of California, Berkeley, Berkeley, California 94720-1650, and ${ }^{3}$ Department of \\ Anatomy and Neurobiology, Colorado State University, Fort Collins, Colorado 80523
}

In adult male rats, spinal nucleus of the bulbocavernosus (SNB) motoneurons shrink after castration and are restored in size after androgen treatment. Sixty-day-old Sprague Dawley males were castrated and implanted with SILASTIC capsules containing testosterone $(\mathrm{T})$ or nothing, and osmotic minipumps continuously infusing MK-801, a noncompetitive NMDA receptor antagonist, or saline. Twenty-five days later, bulbocavernosus muscles were injected with the retrograde tracer cholera toxinhorseradish peroxidase conjugate (CT-HRP) to label SNB cells. As seen previously, among saline-treated rats, SNB somata of T-treated castrates were significantly larger than those of castrates receiving blank capsules ( $p<0.0001$ ). MK-801 treatment blocked this effect of T on the SNB. MK-801 had no effect on non-androgen-responsive spinal motoneurons in the neighboring retrodorsolateral nucleus (RDLN), nor did the drug affect SNB soma size in the absence of androgen treatment. Mo-

The rat spinal nucleus of the bulbocavernosus (SNB) in the lower lumbar spinal cord is a sexually dimorphic group of motoneurons that innervates the bulbocavernosus and levator ani muscles (BC/ LA) attached to the base of the penis (Breedlove and Arnold, 1981). In rats, these motoneurons and their targets are necessary for ejaculation and male copulatory behavior (Sachs, 1982). The morphology of SNB motoneurons is maintained by testicular androgens secreted in adulthood. Castration of adult rats results in a significant decrease in the size of SNB motoneuron somata, nuclei (Breedlove and Arnold, 1981), and dendrites (Kurz et al., 1986); androgen replacement restores these measures. A recent study (Watson et al., 2001) has shown that within rats mosaic for wild-type and defective androgen receptors, only those SNB motoneurons with functional androgen receptors responded to adult androgen treatment with an increase in soma size. Thus, androgens appear to increase soma size through a direct action on SNB motoneurons where functional androgen receptors are necessary for the response to occur. Interestingly, androgens act elsewhere, primarily on the $\mathrm{BC} / \mathrm{LA}$ target muscles, to increase dendritic outgrowth of SNB motoneurons, probably via a retrograde axonal signal (Rand and Breedlove, 1995).

Received May 9, 2002; revised July 29, 2002; accepted Aug. 7, 2002.

This work was supported by National Institute of Neurological Disorders and Stroke Grants NS28421 (S.M.B.), NSF IBN 0296060 (C.L.J.), and NSF IBN 9996385 (R.J.H.).

Correspondence should be addressed to S. Marc Breedlove, Neuroscience Program, Psychology Research Building, Michigan State University, East Lansing, MI 48824. E-mail: breedsm@msu.edu.

Copyright (c) 2002 Society for Neuroscience $0270-6474 / 02 / 229567-06 \$ 15.00 / 0$ toneuronal soma size in Nissl stain revealed the same pattern of results seen with CT-HRP fills. In situ hybridization indicated that SNB motoneurons express mRNA for the NMDA receptor subunits $\mathrm{R} 1, \mathrm{R} 2 \mathrm{a}$, and $\mathrm{R} 2 \mathrm{~b}$. Castration reduced the expression of R1 mRNA in SNB motoneurons, an effect that was blocked by androgen replacement in castrates. R2A and R2B mRNA expression in SNB cells was not affected by androgen manipulations. Likewise, androgen manipulations had no effect on the expression of any NMDA receptor subtypes in RDLN motoneurons. These results suggest that androgen affects the size of SNB motoneurons by influencing their expression of the NMDA receptor, and therefore the response of the motoneurons to endogenous glutamate.

Key words: spinal nucleus of the bulbocavernosus; neural plasticity; NMDA receptor; androgen; motoneurons; MK-801

The NMDA receptor has been implicated in many instances of neural plasticity, including estrogen-induced morphological changes of hippocampal pyramidal cells. Specifically, estradiol administration causes a rapid increase in the spine density of CA1 pyramidal cells; selective antagonism of the NMDA receptor attenuates these effects. Likewise, the estrogen-dependent morphological changes of CA1 pyramidal cells have been directly correlated with an enhanced sensitivity to NMDA receptormediated synaptic input (Woolley et al., 1997). Androgenic modulation of the NMDA receptor has also been reported for the CA1 region of the hippocampus, albeit to a lesser extent. Kus et al. (1995a) reported a decrease in MK-801 receptor binding within CA1 for androgen-treated castrates versus untreated castrates. Androgens also protect CA1 cells from the excitotoxic effects of NMDA (Pouliot et al., 1996). Together these findings suggest that sex steroids and NMDA receptors can interact to bring about changes in neuronal morphology and physiology.

Genes encoding for the NMDA receptor are expressed throughout motoneurons of the rat lumbar spinal cord (Toelle et al., 1995). The presence of NMDA receptors in this region suggests, but by no means proves, that this receptor may participate in the androgen-induced neural response of SNB motoneurons. To assess a possible role of the NMDA receptor in the effects of androgen on SNB soma size, MK-801, a selective NMDA receptor antagonist, was concurrently administered with chronic androgen treatment to castrated adult male rats. We found evidence that such treatment does indeed interfere with the influence of androgen on SNB motoneuronal somata size, but 
does not affect soma size of neighboring, non-androgenresponsive motoneurons. We also found that androgen treatment caused SNB motoneurons to increase expression of the gene for one NMDA receptor subtype. Thus androgen may affect SNB morphology by affecting the sensitivity of the motoneurons to endogenous glutamate.

\section{MATERIALS AND METHODS}

Twenty-eight male Sprague Dawley rats (Charles River Laboratories, Wilmington, MA) were housed in our laboratory $\sim 2$ weeks before treatment. At 55-60 d of age, rats were anesthetized with rat ketamine cocktail $(100 \mathrm{mg} / \mathrm{ml}$ ketamine, $20 \mathrm{mg} / \mathrm{ml}$ xylazine, $10 \mathrm{mg} / \mathrm{ml}$ acepromazine $\mathrm{mg} / \mathrm{ml} ; 0.09 \mathrm{ml} / 100 \mathrm{gm}$ body weight) and castrated through scrotal incisions. Animals were also given subcutaneous implants of two $2-\mathrm{cm}-$ long (effective release length) SILASTIC capsules (1.6 mm inner diameter; $3.2 \mathrm{~mm}$ outer diameter; constructed as in Smith et al., 1977) containing either crystalline testosterone (T) or nothing (blank) and an osmotic mini-pump containing either MK-801 or saline vehicle alone. For implantation, an incision $\sim 5 \mathrm{~cm}$ long was made in a shaved, cleaned area of skin between the scapulas, and a subcutaneous pocket was formed via blunt dissection. The infusion end of the minipump was placed away from the site of incision, and the incision was closed with four or five wound clips. The reservoir capacity of the osmotic minipumps used (Alzet model 2ML4; Alza, Palo Alto, CA) is $\sim 2 \mathrm{ml}$ and provides a 2.5 $\mu \mathrm{l} / \mathrm{hr}$ constant infusion rate for $28 \mathrm{~d}$. (+)-MK-801 hydrogen maleate (Research Biochemicals, Natick, MA) was dissolved in sterile saline to deliver $0.36 \mathrm{mg} \cdot \mathrm{kg}^{-1} \cdot \mathrm{d}^{-1}$ and loaded into the osmotic minipumps according to the manufacturer's instructions. This dose of MK-801 approaches the maximum dose possible for $28 \mathrm{~d}$ infusions, given the size of the osmotic capsules appropriate for rats and the solubility of the drug in aqueous solution.

After surgery, animals were housed in pairs and observed twice a day for $2 \mathrm{~d}$ to monitor recovery. Animals were observed periodically for 1 week after surgery to assess any behavioral side effects caused by the MK-801 treatment. As reported by others delivering the same MK-801 regimen (Lewin et al., 1994), some motor disturbances (ataxia and an overall reduction in movement) were observed in several MK-801treated animals in the first few days after surgery; these effects were temporary and subsided over the course of treatment. Animals were weighed on the day of surgery and 14 and $28 \mathrm{~d}$ after surgery to confirm the previously reported effects of MK-801 on body weight gain (Wessinger, 1994).

Twenty-five days after castration, $1 \mu \mathrm{l}$ of $0.2 \%$ cholera toxinhorseradish peroxidase conjugate (CT-HRP; List Biologic, Campbell, CA) was injected into each side of the bulbocavernosus muscle under ketamine cocktail anesthesia. Three days after injection, animals were given an intraperitoneal overdose of pentobarbital and perfused through the heart with $50 \mathrm{ml}$ of PBS followed by $200 \mathrm{ml}$ of phosphate-buffered $1 \%$ paraformaldehyde and $1.25 \%$ glutaraldehyde. The lower lumbar portion of the spinal cord was removed and placed in fixative for $\sim 2 \mathrm{hr}$ at $4^{\circ} \mathrm{C}$. The cords were then transferred to a $10 \%$ phosphate-buffered sucrose solution and refrigerated overnight. Seminal vesicles and BC/LA muscles were dissected out and placed in $4 \%$ buffered formalin for at least 4 weeks. After this time, the $\mathrm{BC} / \mathrm{LA}$ muscles were trimmed of surrounding fat and connective tissue. The BC/LA muscles and seminal vesicles were then weighed by an observer blind to group membership of the specimens.

On the day after killing, spinal cords were frozen-sectioned $(50 \mu \mathrm{m})$ on a sliding microtome in the transverse plane. Sections were reacted with tetramethylbenzidine for histological visualization of the CT-HRP according to Mesulam (1978). After the reaction, alternate sections were mounted on gelatin-coated slides, dehydrated in ethanol, cleared in xylene, and coverslipped. A set of alternate reacted sections was Nisslstained with Neutral Red.

For each animal, CT-HRP-stained SNB motoneurons with clearly defined cell bodies and nuclei were randomly selected and photographed using a Zeiss light microscope and a digital camera. Digital images were transferred to a Macintosh computer, and the two-dimensional area of motoneuron somata was measured using NIH Image. Fifteen somata were measured and averaged to provide a single estimate of SNB motoneuron size for each rat.

From the Nissl-stained, alternate sections, 15-20 SNB motoneurons that did not contain CT-HRP label were traced using a camera lucida, scanned into the computer, and measured with NIH image. Because
SNB motoneurons innervate three different targets (BC, LA and the external anal sphincter), the HRP-filled motoneurons in this study, innervating the $\mathrm{BC}$, are a subset of the SNB motoneurons examined in Nissl-stained material. The Nissl-stained sections also contained the retrodorsolateral nucleus (RDLN) of motoneurons, which do not respond morphologically to androgen. Twenty to $25 \mathrm{RDLN}$ motoneurons from each animal were traced, and their soma size was determined as above.

Data analysis for each measure consisted of a simple two-way ANOVA with androgen treatment as one factor, MK-801 drug treatment as the other, and $N$ equaled the number of animals. All reported $p$ values are two-tailed.

In a second experiment, adult Sprague Dawley male rats were either castrated or sham-operated as above. Among the castrates, 10 received blank SILASTIC capsules, whereas 8 received capsules containing T. Nine males were sham castrated and implanted with blank SILASTIC capsules. Four weeks later the animals were killed by rapid decapitation, and the spinal cords were quickly removed and frozen in $\mathrm{CO}_{2}$-cooled isopentane. The cords were held at $-80^{\circ} \mathrm{C}$ until transversely sectioned at $10 \mu \mathrm{m}$ in a cryostat. The sections were thaw mounted on to Superfrost Plus slides (Fisher Scientific, Pittsburgh, PA) and stored at $-80^{\circ} \mathrm{C}$ in slides boxes with dessicant until in situ hybridization was performed.

Spinal cord sections were examined for NMDA R1, R2a, R2b, R2c and R2d mRNA levels using in situ hybridization as previously described (Kus et al., 1995b). Synthetic oligonucleotide probes were used for detecting NMDA receptor subunit mRNAs. Their sequences were as follows: NMDA R1: 5' - CTT CGC ACG GTG, CCG, CCC TAC TCC cac CAG TCC AGC GTC TGG TTT-3'; NMDA R2a: 5'-TCG GGA GTT CCC TTT GGA TTC AGT GCT GAC AGC CAC CTC TAC TGT-3'; NMDA R2b: 5'-CAT GTT CTT GGC CGT GCG GAG CAA GCG TAG GAT GTT GGA GTG GGT-3'; NMDA R2c: 5' -CCA GGT TTC TTG CCC TTG GTG AGG TTC TGG TTG TAG CT-3'; and NMDA R2d: 5'-CTG TGG CTC GAT GGG GCC GTA GTA TCG GTG GAA GCC GTC GGC TAG-3'. Probes were synthesized by BioSynthesis, Inc. (Louisville, TX) and end-labeled using terminal deoxynucleotide transferase and ${ }^{35} \mathrm{~S}$-dATP. For assay, frozen tissue sections were thawed at room temperature, fixed in $4 \%$ formalin, acetylated with acetic anhydride $(0.25 \%$ in $0.1 \mathrm{M}$ triethanolamine- $\mathrm{HCl} / 0.9 \%$ saline, $\mathrm{pH}$ 8.0), dehydrated in ascending ethanols, and delipidated in chloroform. Hybridization for each of the NMDA subunits was overnight at $45^{\circ} \mathrm{C}$ under glass coverslips. Hybridization buffer contained $1.2 \mathrm{~mm}$ $\mathrm{NaCl}, 20 \mathrm{~mm}$ Tris, 2 mm EDTA, $0.02 \%$ salmon testis DNA, $0.1 \%$ yeast RNA, $0.04 \%$ Denhardt's solution, and $20 \%$ dextran sulfate. After hybridization, tissue sections were first washed in $2 \times$ SSC to remove the coverslips followed by washes with increasing stringency up to $0.1 \times$ $\mathrm{SSC} / 50 \%$ formamide at $45^{\circ} \mathrm{C}$. Slides were air-dried and initially exposed to $\mathrm{x}$-ray film to check for hybridization intensity. Slides were then emulsion-coated with Kodak NTB-2 and exposed for 15 d (NMDA R1) to 3 weeks (NMDA R2a-d). After developing, tissue was lightly counterstained with cresyl violet, and slides were cleaned and then coverslipped using Permount (Fisher Scientific). For each NMDA receptor subunit, all sections were processed in a single assay to minimize variance.

The intensity of hybridization to spinal cord tissue sections was quantified by grain-counting techniques. Emulsion-coated slides were individually coded. An experimenter blind to treatment group identified the SNB and RDLN in each section. Using a CCD camera (Sony XC-77) mounted on a Zeiss Axiophot microscope, the image of the SNB or RDLN was displayed on a computer monitor with an $8 \times 8$ grid overlay on the screen. Motoneurons were randomly selected based on their location on the computer screen. Only those motoneurons that were displayed at the intersection of the grid lines were selected. All sections containing the SNB were examined and from these sections, between 7 and 12 SNB or RDLN motoneurons per animal were selected for grain counting. Each motoneuron was examined under high power $(40 \times)$ and displayed on the computer screen. Individual silver grains over the motoneuron and within the borders of its soma, were identified based on visual inspection and counted by hand. Grains over an adjacent acellular region were also counted as an index of background hybridization. There was no difference in background grains across treatment groups. The average number of grains per neuron were calculated per animal, and that number was used to represent the animal in statistical analyses. 
Table 1. Effect of T and MK-801 on mean \pm SEM seminal vesicle weight (left) and mean weight of BC/LA target muscles of the SNB (right)

\begin{tabular}{|c|c|c|c|c|}
\hline & \multicolumn{2}{|c|}{ Seminal vesicle weight $(\mathrm{gm})$} & \multicolumn{2}{|c|}{ BC/LA weight (gm) } \\
\hline & Saline & MK-801 & Saline & M K-801 \\
\hline Blank & $0.20 \pm .02(7)$ & $0.18 \pm .01(7)$ & $0.74 \pm 0.08(7)$ & $0.54 \pm 0.03(7)$ \\
\hline Testosterone & $1.85 \pm .15(8)$ & $1.97 \pm .09(7)$ & $1.84 \pm 0.06(8)$ & $1.86 \pm 0.07(7)$ \\
\hline
\end{tabular}

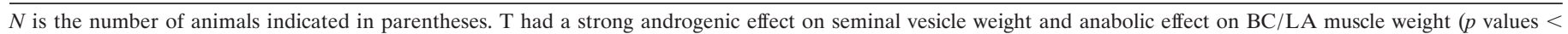
$0.0001)$. MK-801 treatment did not affect either of these measures, nor was there any statistical interaction of androgen and MK-801 ( $p$ values $>0.10)$.

\section{RESULTS}

As expected, there were no significant differences in body weights of groups on the day of surgery. Separate two-way ANOVAs conducted on body weights measured on days 14 and 28 of treatment confirmed that the MK-801-treated animals gained weight more slowly than saline-treated animals. However, there was a significant interaction between androgen and drug for both days (day 14: $F_{(1,24)}=7.40, p<0.05$; day 28: $F_{(1,24)}=4.28, p<$ $0.05)$. The blank/MK-801-treated group gained significantly less weight than the saline groups on both treatment days (blank/MK801 vs T/saline, and blank/MK-801 vs blank/saline, two-tailed $t$ tests, $p$ values $<0.05$ ); however, MK-801-treated castrates receiving $\mathrm{T}$ did not differ significantly from the saline groups. Thus, MK-801 treatment reduced weight gain, but only in castrates not receiving androgen replacement.

Also as predicted, the seminal vesicle weights of blank-treated castrates were significantly smaller than those of T-treated castrate males ( $p<0.0001$; main effect of androgen) (Table 1). There were no main effects of MK-801 treatment, nor any significant interaction of drug and hormone treatment on seminal vesicle weight. BC/LA weights showed a very similar response (Table 1) with the same pattern of statistical significance. Thus, $\mathrm{T}$ exerted a strong androgenic effect on seminal vesicles and anabolic effect on $\mathrm{BC} / \mathrm{LA}$ muscle weights, neither of which was significantly affected by MK-801 treatment.

The soma area analysis of CT-HRP-labeled SNB motoneurons (Fig. 1) revealed a main effect of androgen $\left(F_{(1,20)}=35.39 ; p<\right.$ $0.0001)$ and an interaction between androgen and drug treatment $\left(F_{(1,20)}=9.05 ; p<0.007\right)$. Post hoc comparisons revealed that $\mathrm{T} /$ saline-treated castrates had significantly larger somata than T/MK-801-treated castrates $(p<0.05)$. However, T/MK-801treated castrates were not significantly different from blank/MK801 castrates $(p>0.05)$. Finally, blank/MK-801 and blank/ saline-treated castrates did not significantly differ, indicating that MK-801 did not reduce SNB soma size in the absence of $\mathrm{T}$ treatment. Thus, the statistically significant interaction of MK801 and androgen treatment seems to be caused by MK-801 treatment blocking the effect of androgen on SNB soma size.

This interaction between androgen and drug treatment was also apparent in the size of Nissl-stained SNB somata $\left(F_{(1,21)}=\right.$ 4.93; $p<0.05)$ from the same animals. SNB somata from $\mathrm{T} /$ Saline castrates were significantly larger that those from T/MK-801 and blank/Saline castrates ( $p<0.05$ for both); no other group differences were found (Table 2). So again MK-801 treatment masked the effect of T replacement on SNB soma size in castrates. As we have seen previously (Rand and Breedlove, 1995), the apparent size of SNB somata is smaller in Nissl-stained material than in HRP-filled material, presumably because the HRP fill offers a more complete view of the somata and primary dendrites.

As predicted, the androgen treatment had no significant effect on the size of RDLN somata $\left(F_{(1,21)}=0.28 ; p>0.50\right)$, and the

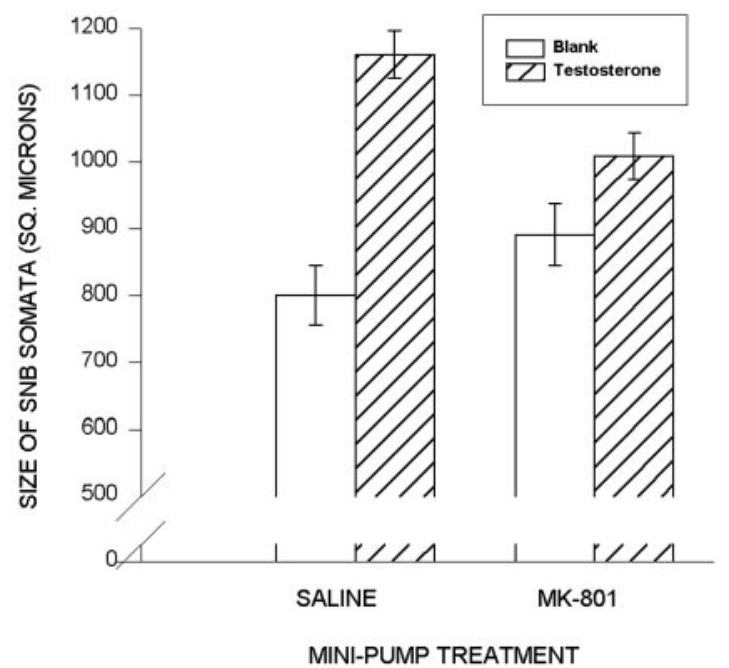

Figure 1. MK-801 blocks the activational effects of T on SNB soma size. Mean areas ( \pm SEM) of CT-HRP-labeled SNB motoneuron somata. An ANOVA revealed a significant interaction between androgen and drug treatment. Left, T-treated castrates had significantly larger somata than did castrates without hormone replacement. Right, However, in MK-801treated animals, $\mathrm{T}$ had no significant effect.

Table 2. Mean areas \pm SEM of Nissl-stained SNB motoneuron somata

\begin{tabular}{lll} 
& Saline $\left(\mu \mathrm{m}^{2}\right)$ & MK-801 $\left(\mu \mathrm{m}^{2}\right)$ \\
\hline Blank & $472.26 \pm 19.96^{*}(7)$ & $489.34 \pm 23.8(5)$ \\
Testosterone & $561.79 \pm 24.23(7)$ & $485.96 \pm 11.06^{*}(6)$
\end{tabular}

$N$ is the number of animals indicated in parentheses. An ANOVA revealed the same interaction between androgen and drug treatment that was detected in the analysis of CT-HRP-labeled somata depicted in Figure 1. Androgen increased SNB soma size only in the absence of MK-801 treatment.

*Significantly different from $\mathrm{T} /$ Saline castrates $(p<0.05)$.

size of Nissl-stained somata was approximately the same in the SNB and RDLN. However, there was no significant main effect of MK-801 treatment $\left(F_{(1,21)}=0.21 ; p>0.50\right)$ nor an interaction of MK-801 and androgen $\left(F_{(1,21)}=2.95 ; p>0.10\right)$ for RDLN measures (Fig. 2). Thus, MK-801 had no effect on the size of non-androgen-responsive RDLN motoneurons from these animals.

In situ hybridization revealed that spinal motoneurons expressed NMDA receptor $1,2 \mathrm{a}$, and $2 \mathrm{~b}$, as reported by others. However, R1 expression was greater in SNB motoneurons than in RDLN motoneurons. Furthermore, androgen manipulations affected R1 expression levels in SNB cells (Fig. 3). SNB motoneurons from control-treated castrates displayed less labeling than did SNB cells from either sham-operated males or castrates treated with $\mathrm{T}(p$ values $<0.05)$. Androgen had no effect on NMDA R1 expression in RDLN motoneurons. The other two 


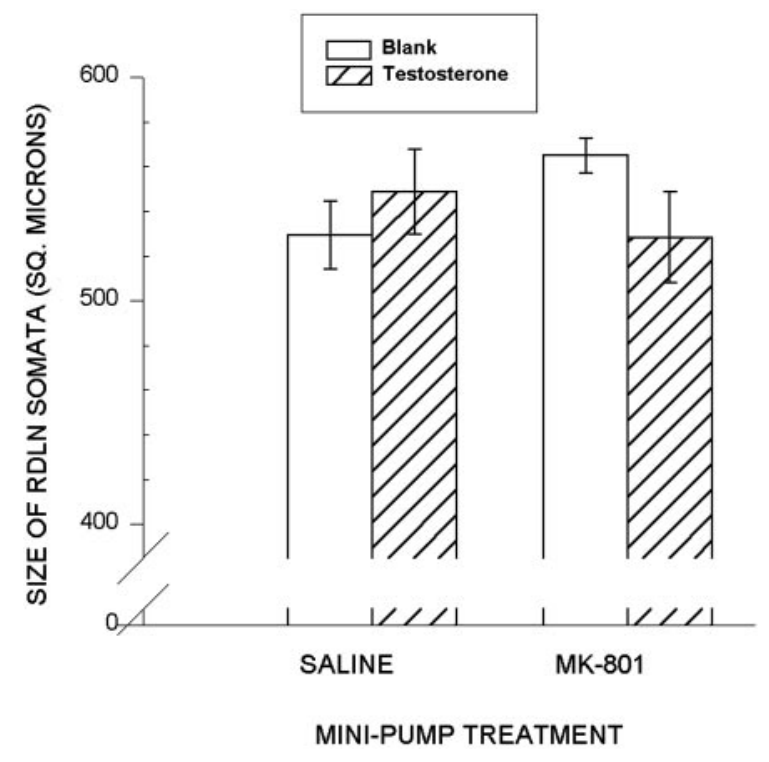

Figure 2. Neither androgen nor MK-801 treatment significantly affected Nissl-stained soma size of spinal motoneurons in the rat RDLN, nor was there any significant interaction of the two factors for this measure. These findings indicate that MK-801 does not have a general, shrinking effect on rat spinal motoneurons. Note that these soma sizes from Nissl stain are, as expected, smaller than the HRP-filled somata represented for SNB motoneurons in Figure 1. Comparable measures for Nissl-stained SNB motoneurons are presented in Table 2.

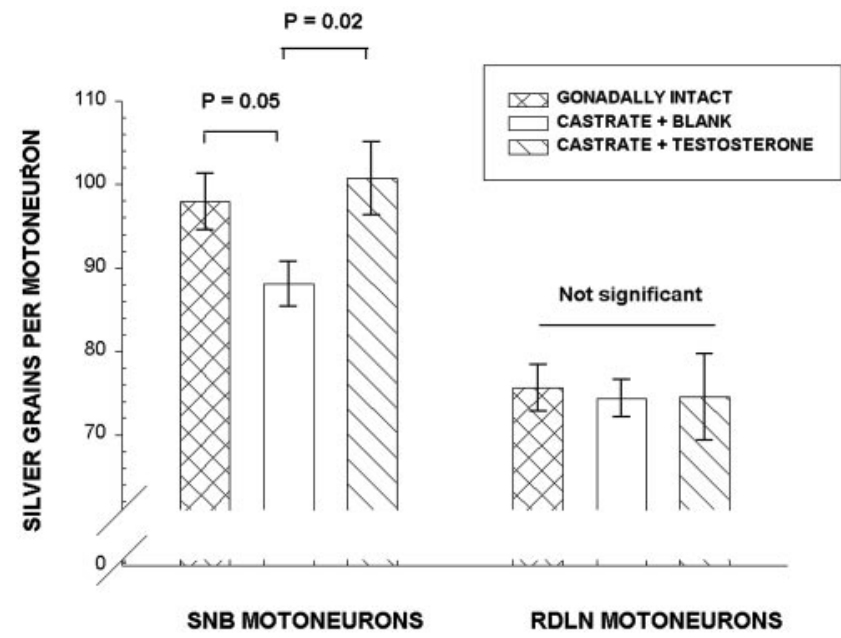

Figure 3. Castration reduces the expression of the NMDA R1 gene in rat SNB motoneurons, an effect that is prevented if the castrates are given testosterone. In contrast, RDLN motoneurons (right), which also express the NMDA R1 gene, do not alter expression of the gene in response to androgen manipulations.

NMDA receptor subunits were not affected by androgen manipulations in either the SNB (Fig. 4) or the RDLN (data not shown). There was no specific hybridization for the NMDA R2c or R2d message in either motoneuronal pool in any group (data not shown).

\section{DISCUSSION}

MK-801 blocked the effects of testosterone on SNB soma size. The MK-801 treatment only affected cell size in animals treated with $\mathrm{T}$, indicating that its effect is dependent on the presence of androgen. MK-801 had no effect on the androgen-unresponsive

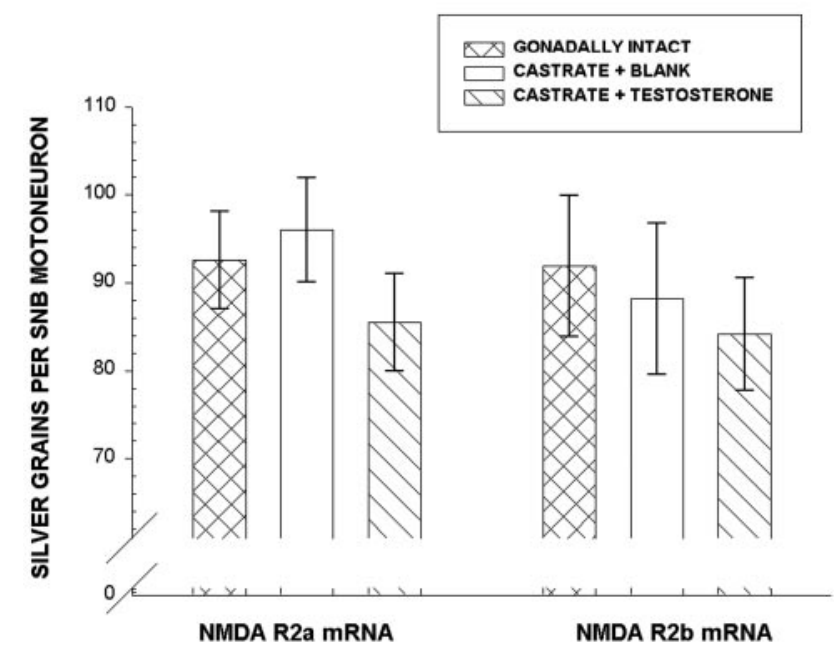

Figure 4. Androgen manipulations do not affect the expression of NMDA R2a or NMDA R2b in rat SNB motoneurons or RDLN motoneurons (data not shown).

RDLN motoneurons from the same spinal sections, indicating that the drug does not have a nonspecific effect of shrinking motoneurons. Indeed, among castrates not receiving $\mathrm{T}$, the mean size of motoneurons in each nucleus was slightly, but not significantly, larger in MK-801 animals than in those receiving saline. These findings suggest that the NMDA receptor may play a role in the cellular mechanism by which androgen exerts morphological changes in adult motoneurons of the SNB.

A number of alternative explanations can be considered. First, the MK-801 treatment may have disrupted normal binding of testosterone to the androgen receptor, which led to a subsequent reduction in the androgen-mediated change in soma size. However, the seminal vesicles and the $\mathrm{BC} / \mathrm{LA}$ muscles of the T-treated animals were identical among the drug and vehicle treatments, indicating that MK-801 does not interfere with androgen receptor binding, at least in peripheral structures. This does not rule out the possibility that in SNB motoneurons, MK801 somehow acts on NMDA receptors to alter androgens binding to their receptor in those motoneurons. The current results could also be explained if the MK-801 treatment suppressed normal androgen receptor expression. Again the peripheral structure weights do not support this explanation: global reduction of androgen receptor expression by MK- 801 would be expected to reduce peripheral structure weights for MK-801 animals receiving testosterone. Last, it is theoretically possible that the changes in SNB soma size seen after androgen treatment are attributable to the binding of $\mathrm{T}$ to NMDA receptors and not to androgen receptors. However, Watson et al. (2001) examined rats mosaic for wild-type and defective androgen receptors and found that functional androgen receptors were necessary for SNB motoneurons to respond to androgens with an increase in size. The same study found that bound androgen receptors reside within the nucleus, indicating that the androgen receptors induce somatic changes in the SNB through a genomic action.

So it appears likely that NMDA receptors and androgens normally interact to influence SNB morphology. There are several possible means by which this interaction could occur. First, although we know that androgens act directly on SNB motoneurons to increase their soma size, we do not know the locus at which MK-801 acts to interfere with this effect. One possibility is 
that androgens directly affect NMDA receptor expression or activity within the SNB.

There is precedent for this idea. In the rat hippocampus, estradiol treatment in ovariectomized rats increases the number of NMDA receptor binding sites in the hippocampus (Weiland, 1992). Gazzaley et al. (1996) showed that the mechanism for this estradiol-dependent change is likely attributable to an increased production of the NMDA R1 subunit protein. Morphologically, estradiol increases spine density of CA1 pyramidal cells, an effect that is dependent on NMDA receptor activation (Woolley and McEwen, 1993). Subcutaneous injections of MK-801 blocked the increase in spine density of these cells in the presence of estradiol (Woolley and McEwen, 1994). Likewise, long-term potentiation is increased as estrogen levels increase naturally within the rat estrous cycle (Warren et al., 1995). Last, Woolley et al. (1997) showed that estradiol treatment of CA1 pyramidal cells increased their sensitivity to synaptic input mediated by the NMDA receptor. This increase in sensitivity was significantly correlated with the estradiol-induced increase in spine density, suggesting that both the steroid and drug were acting directly on these neurons.

The role of androgens in NMDA receptor expression has also been examined in the CA1 pyramidal layer of rats, but only at the level of ligand binding. Interestingly, Kus et al. (1995a) found that NMDA receptor binding was reduced in this region for male castrates receiving androgen compared with nontreated castrates. However, within the ventral and medial regions of the lateral septum, NMDA receptor binding was increased by androgen treatment of castrates (Kus et al., 1995b). An interaction of androgens and NMDA receptors in the neurophysiology of hippocampal CA1 cells was suggested when chronic dihydrotestosterone propionate administration was found to protect such cells from an NMDA-induced irreversible depolarization (Pouliot et al., 1996). Both androgens and estrogens, then, cause neurophysiological changes in hippocampal pyramidal cells via an NMDA receptor mechanism. These findings strengthen the possibility that androgens and the NMDA receptor may interact in the rat SNB system. Our data directly confirmed this possibility.

There have been several reports that spinal motoneurons possess NMDA receptors (Kalb et al., 1992; Toelle et al., 1995; Croul et al., 1998), including a recent report of NMDA R1 immunoreactivity in SNB motoneurons (Gougis et al., 2002). The current findings indicate that NMDA receptor genes are indeed expressed by SNB motoneurons and that androgen manipulations alter the level of NMDA receptor expression by these cells. Taken together, these findings suggest a specific mechanism of action. When androgen induces SNB motoneurons to increase the expression of NMDA receptor genes, this may increase the sensitivity of the cells to glutamate stimulation of the resultant receptors. It may be this activation of NMDA receptors that then causes SNB motoneurons to enlarge (Breedlove, 1997). Because the same androgen treatments that increase SNB somata size also increase SNB dendritic extent (Kurz et al., 1986) and the penile reflexes (Hart 1973) mediated by SNB target muscles, NMDA receptors may also mediate these effects of androgen (Leedy et al., 1987; Matsumoto et al., 1988). There are no studies of the physiological effects of NMDA receptor activation specifically in SNB motoneurons. However, studies of other spinal motoneurons indicate that activation of NMDA receptors increases spontaneous activity (McCrimmon et al., 1989; Abdrachmanova et al., 2002).

It is interesting that neighboring RDLN motoneurons also express NMDA receptor genes, but do not modulate the expres- sion of this gene when androgens are manipulated. Likewise, RDLN motoneurons do not respond to androgens by increasing their somata size nor do they respond to the NMDA receptor antagonist MK-801, either in the presence or absence of androgens. These results suggest that not all NMDA-receptive neurons modulate receptor expression in the face of changes in androgen levels. Perhaps the ability of androgen to modulate NMDA receptor expression is a requirement for neurons to respond morphologically to the hormone. Of course, this begs the question of why some neurons change NMDA expression after androgen manipulations, whereas other neurons do not. It cannot be a simple matter of whether the neurons possess androgen receptors, because RDLN motoneurons possess androgen receptors, as shown by autoradiography (Breedlove and Arnold, 1983) and immunocytochemistry (Freeman et al., 1995). Both of these reports suggest that RDLN motoneurons have fewer androgen receptors than do SNB motoneurons, so there may be some threshold effect, in which a particular concentration of androgen receptors is required for androgens to modulate NMDA expression. On the other hand, there are some cases when rat motoneurons differ markedly in their morphological response to androgen, but show no apparent difference in androgen receptor complement (Jordan, 1997). So androgen receptors may be necessary, but are not sufficient, to confer androgen-induced plasticity to motoneurons.

The study of sex steroid-NMDA receptor interactions has been primarily restricted to the rat hippocampus; we report here that a similar interaction may occur in the spinal cord. These findings suggest that steroids may commonly act through NMDA receptors to modulate neuronal plasticity throughout the neuraxis, a hypothesis that might be usefully tested in other neural systems affected by steroid hormones.

\section{REFERENCES}

Abdrachmanova G, Teisinger J, Vyklicky Jr L (2002) Axotomy-induced changes in the properties of NMDA receptor channels in rat spinal cord motoneurons. J Physiol (Lond) 538:53-63.

Breedlove SM (1997) Adult sexual experience alters neuronal morphology. Nature 389:801.

Breedlove SM, Arnold AP (1981) Sexually dimorphic motor nucleus in the rat lumbar spinal cord: response to adult hormone manipulation, absence in androgen-insensitive rats. Brain Res 225:297-305.

Breedlove SM, Arnold AP (1983) Sex differences in the pattern of steroid accumulation by motoneurons of the rat lumbar spinal cord. J Comp Neurol 215:211-216.

Croul S, Radzievsky A, Sverstiuk A, Murray M (1998) NK1, NMDA, $5 \mathrm{HT} 1 \mathrm{a}$, and 5HT2 receptor binding sites in the rat lumbar spinal cord: modulation following sciatic nerve crush. Exp Neurol 154:66-79.

Freeman LM, Padgett BA, Prins GA, Breedlove SM (1995) Distribution of androgen receptor immunoreactivity in the spinal cord of wild-type, androgen-insensitive and gonadectomized male rats. J Neurobiol 27:51-59.

Gazzaley AH, Weiland NG, McEwen BS, Morrison JH (1996) Differential regulation of NMDAR1 mRNA and protein by estradiol in the rat hippocampus. J Neurosci 16:6830-6838.

Gougis S, Prud'homme M-J, Rampin O (2002) Presence of the $N$-methyl-D-aspartic acid R1 glutamatergic receptor subunit in the lumbosacral cord of male rats. Neurosci Lett 323:224-228.

Hart BL (1973) Effects of testosterone propionate and dihydrotestosterone on penile morphology and sexual reflexes of spinal male rats. Horm Behav 4:239-246.

Jordan CL (1997) Androgen receptor (AR) immunoreactivity in rat pudendal motoneurons: implications for accessory proteins. Horm Behav 32:1-10.

Kalb RG, Lidow MS, Halsted MJ, Hockfield S (1992) N-methyl-Daspartate receptors are transiently expressed in the developing spinal cord ventral horn. Proc Natl Acad Sci USA 89:8502-8506.

Kurz EM, Sengelaub DR, Arnold AP (1986) Androgens regulate the dendritic length of mammalian motoneurons in adulthood. Science 232:395-398.

Kus L, Handa RJ, Hautman JM, Beitz AJ (1995a) Castration increases 
[125I]M K801 binding in the hippocampus of male rats. Brain Res 683:270-274.

Kus L, Handa RJ, Sanderson JJ, Kerr JE, Beitz AJ (1995b) Distribution of NMDAR1 receptor subunit mRNA and [125I]M K801 binding in the hypothalamus of intact, castrate and castrate-DHTP treated male rats. Mol Brain Res 28:55-60.

Leedy MG, Beattie MS, Bresnahan JC (1987) Testosterone-induced plasticity of synaptic inputs to adult mammalian motoneurons. Brain Res 424:386-390.

Lewin GR, McKintosh E, McMahon SB (1994) NMDA receptors and activity-dependent tuning of the receptive fields of spinal cord neurons. Nature 369:482-485.

Matsumoto A, Micevych PE, Arnold AP (1988) Androgen regulates synaptic input to motoneurons of the adult rat spinal cord. J Neurosci 8:4168-4176.

McCrimmon DR, Smith JC, Feldman JL (1989) Involvement of excitatory amino acids in neurotransmission of inspiratory drive to spinal respiratory motoneurons. J Neurosci 9:1910-1921.

Mesulam M (1978) Tetramethyl benzidine for horseradish peroxidase neurohistochemistry: a non-carcinogenic blue reaction-product with superior sensitivity for visualizing neural afferents and efferents. J Histochem Cytochem 26:106-117.

Pouliot WA, Handa RJ, Beck SG (1996) Androgen modulates $N$-methylD-aspartate-mediated depolarization in CA1 hippocampal pyramidal cells. Synapse 23:10-19.

Rand MN, Breedlove SM (1995) Androgen alters the dendritic arbors of SNB motoneurons by acting on their target muscles. J Neurosci 15:4408-4416.

Sachs BD (1982) Role of the rat's striated penile muscles in penile reflexes, copulation and the induction of pregnancy. J Reprod Fertil 66:433-443.

Smith ER, Damassa DA, Davidson JM (1977) Hormone administration: peripheral and intracranial implants. Methods Psychobiol 3:257-279.

Toelle TR, Berthele A, Laurie DJ, Seeburg PH, Zieglgansberger W (1995) Cellular and subcellular distribution of NMDAR1 splice variant mRNA in the rat lumbar spinal cord. Eur J Neurosci 7:1235-1244.

Warren SG, Humphreys AG, Juraska JM, Greenough WT (1995) LTP varies across the estrous cycle: enhanced synaptic plasticity in proestrus rats. Brain Res 703:26-30.

Watson NV, Freeman LM, Breedlove SM (2001) Neuronal size in the spinal nucleus of the bulbocavernosus (SNB): direct modulation by androgen in animals with mosaic androgen insensitivity. J Neurosci 21:1062-1067.

Weiland NG (1992) Estradiol selectively regulates agonist binding sites on the $N$-methyl-D-aspartate receptor complex in CA1 region of the hippocampus. Endocrinology 131:662-668.

Wessinger W (1994) Tolerance to and dependence on MK-801 (dizocilpine) in rats. Pharmacol Biochem Behav 49:1049-1056.

Woolley CS, McEwen BS (1993) Roles of estradiol and progesterone in regulation of hippocampal dendritic spine density during the estrous cycle in the rat. J Comp Neurol 336:293-306.

Woolley CS, McEwen BS (1994) Estradiol regulates hippocampal dendritic spine density via an $N$-methyl-D-aspartate receptor-dependent mechanism. J Neurosci 14:7680-7687.

Woolley CS, Weiland NG, McEwen BS, Schwartzkroin PA (1997) Estradiol increases the sensitivity of hippocampal CA1 pyramidal cells to NMDA receptor-mediated synaptic input: correlation with dendritic spine density. J Neurosci 17:1848-1859. 